\title{
Relationship between Geotechnical Properties and Road Failures along Ilorin - Ajase Ipo Road Kwara State, Nigeria.
}

\author{
${ }^{1 * *}$ A. A. Kekere, ${ }^{2}$ L .O. Lawal, ${ }^{3}$ G.P. Awotayo \\ ${ }^{1}$ Department of Art and social sciences, Unilorin secondary school, P.M.B 1515, University of Ilorin, Ilorin. \\ Nigeria. \\ ${ }^{2,3}$ Department of Geography Kwara State College of Education Ilorin, Kwara State. Nigeria. \\ ** Corresponding Author.
}

\begin{abstract}
This paper examines the relationship between geotechnical properties and road failure along IlorinAjase Ipo road, Kwara State Nigeria. Soil samples were collected from Five (5) portions of the road that are severely damaged by road failure. These portions include: Agricultural and Rural Management Training Institute (ARMTI) 17+800km, Kabba Owode 18+00Km, Idofian 23+700Km, Koko 29+700Km and Omupo $35+700 \mathrm{Km}$ axis of the road. The soil samples collected were analyzed based on four geotechnical analysis: particle size distribution (PSD), atterberg limit, compaction test california bearing ratio (CBR).Results from geotechnical properties showed that, road foundation has a poorly graded gravel( GP), Well graded gravel $(G W)$,Well graded sand $(S P)$ and poorly graded sand $(S P)$.The result were further subjected to statistical analysis: the stepwise regression indicated that only two (2) variables coefficient of curvature and coefficient of Uniformity contribute to $99.7 \%$ of road failures. The overall results showed that problems soils are the major causes of road failure and the study also observed that poor engineering construction also contribute to the incessant road failures along Ilorin-Ajase-Ipo road.
\end{abstract}

Keyword: Road failure, bitumen, structural failure, problem Soils.

\section{Introduction}

Geotechnical properties include all geologic earth materials which may undergo laboratory analysis before any civil engineering construction takes place. Geotechnical analysis is required because it provides useful information on foundation soils before any civil engineering projects are carried out. Engineering geologist, geotechnical engineers, geomorphologist among other professionals play an integral role in modern engineering project this is because report on geotechnical analysis make them aware of problem- soil with a view to avoid structural failure, defects or collapse of civil engineering projects. It has been observed that problem-soils poses a serious threat to civil engineering projects which results to defect or collapse of infrastructures such as roads, buildings, dams among others. Nigerian soils for example are characterized by various problems-soils zones which several works have reported (see Ola1983;Durotoye 1983; Adesunloye 1987; Omange et'al 1988; Chukweze 1991; and Bolarinwa 2010).In Nigeria, road failure is one of the infrastructural facilities that is in total collapse, road failure has not only caused set back to Nigerian economy but it has claimed lives which results from road crashes and properties worth millions of naira are lost annually. A recent study conducted by Federal Road Safety Corps (FRSC 2011) revealed that 162 death per 10,000 population occur from road crashes in Nigeria and Nigeria currently rank 191 of 192 countries of the world with unsafe roads. Majority of this road network are poorly constructed and they are largely founded on problemsoils such as clay soils and sandy soils and as a results of this rehabilitation of this road network becomes a huge financial burden to Federal government billions of naira are spent annually on reconstruction and rehabilitation across the country. The incessant road failure along Ilorin-Ajase Ipo road has call for concerns to commuters because several hours are spent before getting to their destinations and businesses along Egbe -Kabba road are on a verge of collapse because commuters now prefer the road through Ekiti State which is considered one of the safest road in the region and this has negatively affects the socio economic activities in Egbe-Kabba road Kogi State. However, commuters now the pay additional cost and several hours are spent on each journey the make to Kogi State and its' environs. This study therefore, investigates the relationships between geotechnical properties and road failure.

\section{The Study Area}

Ilorin-Ajase-Ipo Road is one of the four transect route linking the Kwara State capital Ilorin, Nigeria (see Oyegun 1986). It lies between latitude $4^{\circ} 20_{2}^{\prime}$ and $5^{\circ} 303^{\prime}$ North of the equator and between longitude $4^{\circ} 303^{\prime}$ and $5^{\circ} 404^{\prime}$ east of the Greenwich meridian. The road network passes through several towns, villages market and cattle market which enhance the socio economic activities in the area. Apart from the socio economic activities the presence of some federal government agencies such as the Agricultural management training Institute (ARMTI) and National Centre for Agricultural Mechanization (NCAM) makes the road very busy all 
through the year. The road remain the only exit from Kwara to Kogi State, Ekiti State and its' environs and to the Federal Capital Territory (FCT Abuja).

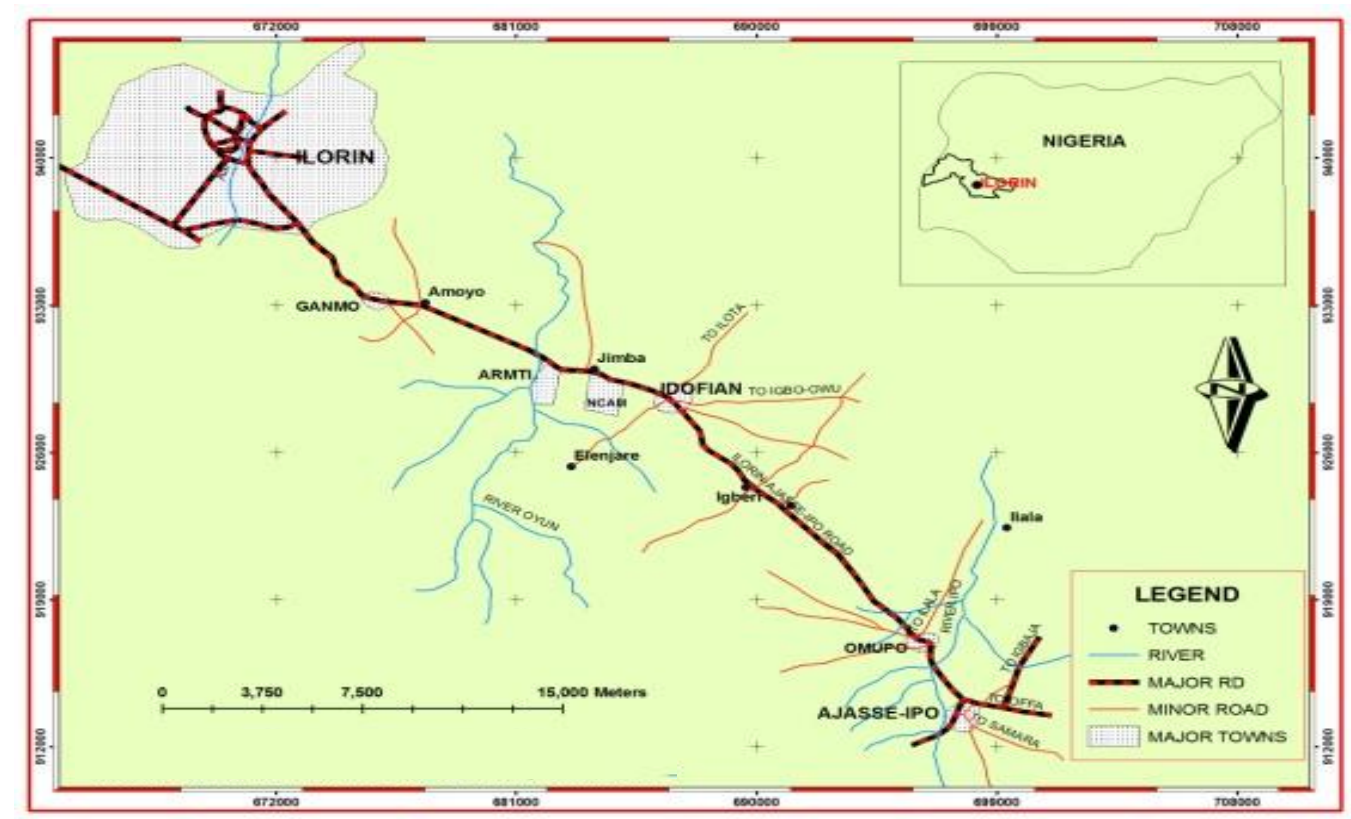

\section{Fig. 1 Ilorin Ajase-Ipo Road, Kwara State, Nigeria. (Source: Office of surveyor General Kwara State, Nigeria).}

Ilorin-Ajasse Ipo Road is found on an undulating plain with a height between 200-300m above sea level, underlain by pre Cambrian basement complex rock which has undergone processes of metamorphism and magnetic intrusion (Oyegun 1995). Generally, the foundation materials of the road network are dominated by sandy soil, clayey soil and some fragmented igneous rock shattered along side of the road. The climate of the area belongs to the humid tropical climate characterized by wet and dry seasons. The two seasons are largely produced by two important air masses; the tropical maritime air masses and the tropical dry continental air masses. The tropical maritime air which originates from the southwesterly direction from the Atlantic ocean and the tropical dry continental air masses flow from North easterly direction from the Sahara desert. IlorinAjasse-Ipo Road falls between Zones D and E of the ITD movement (see Ojo 1977; Olaniran 2002) where vast producing cloud forming rainfall is enhanced thereby given rise to annual rainfall is between $1000-1150 \mathrm{~mm}$ the rainfall exhibit double maximum pattern with a little dry spell around August. This implies that there is adequate soil water to allow other geomorphic processes such as erosion of road sides as well as surface of the road to take place. The temperature ranges between $25^{\circ \mathrm{c}}$ to $28.9^{\circ \mathrm{c}}$ reaching $29^{\circ \mathrm{c}}$ (NIMET Ilorin). The soil belongs to the ferruginous tropical soils which are reddish-brownish in color and it has some proportion clay content. The dominant clay type is the kaolinite clay and illite group. Lateritic iron stone are quite feasible in some segments of the study area.

\section{Materials And Methods}

Soil samples were obtained from foundation of the road; these samples were collected from 5 different locations of the road with worst failure rates. These samples were first air dried under the sun to allow moisture to escape before basic test were performed. The tests were conducted in accordance with the British Standard in the Civil Engineering Department of the University of Ilorin, Ilorin Nigeria. 5 soil geotechnical properties were tested. They include Atterberg limit comprising of liquid limit and plastic limit test, particle size analysis comprising determination of percentage clay, silt and sand the determination of coefficient of uniformity and curvature were also carried out. Other test includes, compaction test and the California Bearing Ratio (CBR) test, which were conducted to test likely failure due to the geotechnical properties along road under investigation. However, particle size Distribution shows composition of sand and gravel more so, plasticity chart was plotted to determine clayey and silty composition of the soil samples under investigation. Results obtained 
in this study were further subjected to statistical analysis. Stepwise regression statistics was used to established relationships between road failure and geotechnical properties.

IV. Results and Discussion

Table.1Soil Geotechnical properties

\begin{tabular}{|c|c|c|c|c|c|c|c|c|c|c|}
\hline \multicolumn{3}{|l|}{ Soil Properties } & \multicolumn{2}{|l|}{$\mathrm{A}$} & \multicolumn{2}{|c|}{ B } & $\mathrm{C}$ & \multirow[t]{2}{*}{$\mathrm{D}$} & \multirow[t]{2}{*}{$\mathrm{E}$} & \\
\hline \multicolumn{3}{|c|}{ Particle size Distribution [PSD] $(\%)$} & \multirow{2}{*}{\multicolumn{2}{|c|}{64}} & & & & & \\
\hline \multicolumn{3}{|c|}{ Grave1 } & & & 66 & & 58 & 5 & 43 & \\
\hline \multicolumn{3}{|l|}{ Sand } & \multicolumn{2}{|l|}{36} & \multicolumn{2}{|c|}{34} & 42 & 95 & 57 & \\
\hline \multicolumn{3}{|l|}{ Liquid Limit (LL) } & \multicolumn{2}{|l|}{41} & \multicolumn{2}{|c|}{43} & 42 & 51 & 42 & \\
\hline \multicolumn{3}{|l|}{ Plasticity Index (PI) } & \multicolumn{2}{|c|}{23} & \multicolumn{2}{|c|}{18} & 25 & 26 & 20 & \\
\hline \multicolumn{3}{|l|}{ Optimum moisture content (OMC) } & \multicolumn{2}{|l|}{14} & \multicolumn{2}{|c|}{13} & 10 & 14 & 13 & \\
\hline \multicolumn{3}{|c|}{ Maximum Dry Density (MDD) $\mathrm{kg} \mathrm{m}$} & \multicolumn{2}{|c|}{1830} & \multicolumn{2}{|c|}{1820} & 1880 & 1800 & 1900 & \\
\hline \multicolumn{3}{|c|}{ Coefficient of uniformity $(\mathrm{CU})$} & \multicolumn{2}{|c|}{8} & \multicolumn{2}{|c|}{7} & 11 & 4 & 16 & \\
\hline \multicolumn{3}{|l|}{ Coefficient of curvature ( $\mathrm{Ccvr}$ ) } & 1 & & 1 & & 2 & 2 & 1 & \\
\hline Soil Classification (USCS) & & & GP & & $\mathrm{G}$ & & GW & SW & $\mathrm{SP}$ & \\
\hline $\begin{array}{l}\text { Source: Authors field work } 201 \\
\text { Table .2 Step Wise Regression }\end{array}$ & $\begin{array}{r}\mathrm{GP} \\
\mathrm{ST} \\
\text { Between }\end{array}$ & $\begin{array}{l}=\text { poor } \\
7=\text { well } \\
\text { geotech }\end{array}$ & $\begin{array}{l}\text { ly g } \\
\text { grac } \\
\text { nic }\end{array}$ & $\begin{array}{l}\text { ade } \\
\text { ed } \\
\text { l p }\end{array}$ & id & $\begin{array}{r}\text { velc } \\
\text { ties }\end{array}$ & $\begin{array}{l}\mathrm{W}=\mathrm{W} \\
\mathrm{P}=\mathrm{p} \circ \mathrm{0} \\
\text { and Ro }\end{array}$ & $\begin{array}{l}1 \text { grade } \\
\text { grad } \\
\text { Failu }\end{array}$ & $\begin{array}{l}\text { gravel } \\
\text { sand } \\
\text { se }\end{array}$ & \\
\hline Variable & Coeff & Stand E & & $\mathrm{T}$ & & Sig & $\% \mathrm{c}$ & atribut & & $\begin{array}{l}\text { Total } \\
\text { contributio } \\
n \%\end{array}$ \\
\hline Constant & 1734.4 & & & & & 000 & & & & \\
\hline Coefficient of uniformity (Cu) & 9.99 .8 & 3.40 & & 24 & & .002 & 99.3 & & & \\
\hline Coefficient of curvature ( $\mathrm{CcVr})$ & 14.814 & & & 6.0 & & .027 & 06.2 & & & 99.7 \\
\hline
\end{tabular}

Source: Author's Field work 2010

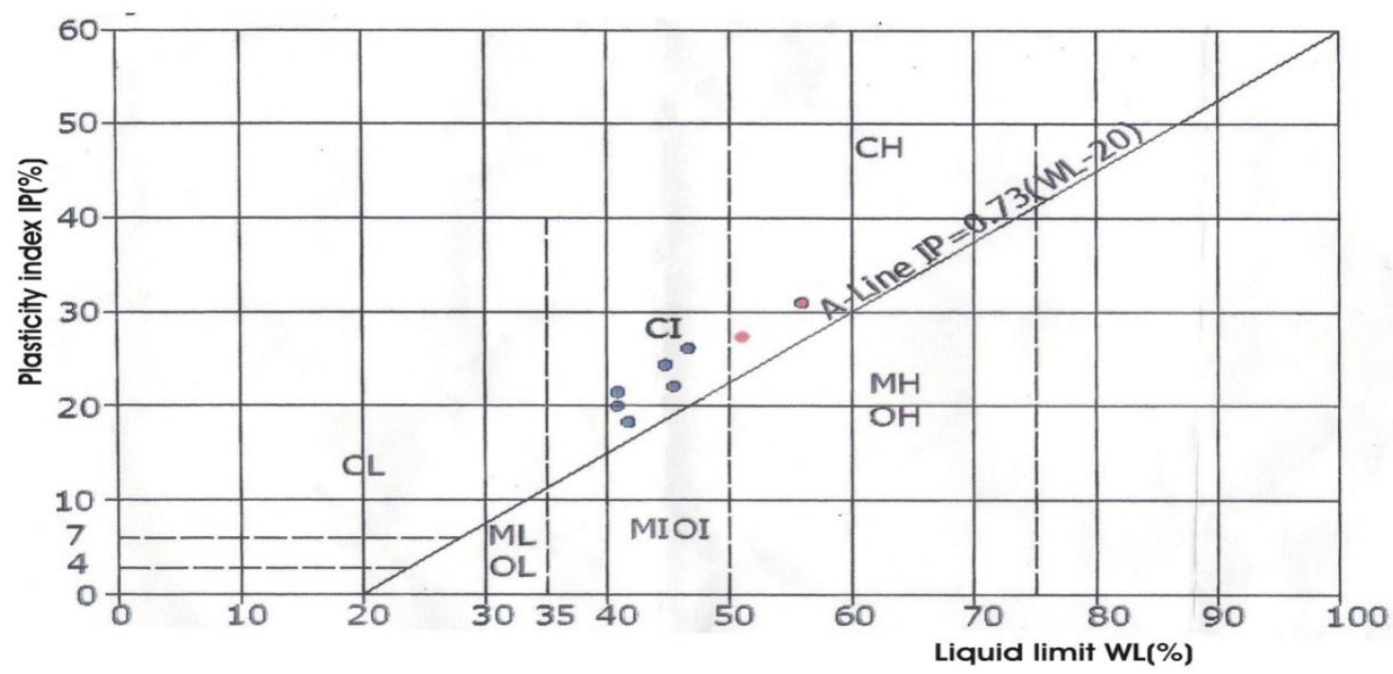

Fig. 3 Plasticity chart for the classification of clayey and silty soil

According to Table 1. Gravel composition is in the range of 5-43\% and sand between 34 and $95 \%$, they were classified as based on Universal Soil Classification System (USCS) as gravely soils, sandy as well as poorly graded soils. This implies that foundation materials were poorly graded with high percentage of sandy soil composition which affects the rate of compaction of the road. The result also shows that moisture content ranges from 10-14\%, Plastic Limit (PL) between 17-26\% and Liquid Limit (LL) $41-51 \%$. This results obtained shows that it is within acceptable limit. However, results of plasticity index (IP) which is plotted on plasticity chart in Fig. 3 above shows that chainage $17+200 \mathrm{Km}, 18+600 \mathrm{Km}, 20+650 \mathrm{Km}$ contain soils of intermediate clay content $(\mathrm{CI})$ while $29+250 \mathrm{Km}$ contained a very high clay content $(\mathrm{CH})$. The presence of clay soil in foundation materials is capable of causing swelling and brokerage of road surfaces when in contact with moisture during wet season this has explained why several potholes are seen on the road network.

The value for maximum Dry Density (MDD) of the foundation soil ranges from $1800-1900 \mathrm{~kg} / \mathrm{m}^{3}$ according to O'Flaherty (2001) this value meet the anticipated value of compaction level for flexible pavement 
condition for low volume vehicle but the increasing axial load of heavy vehicles plying this road with several tones of materials have affected the level of compaction rate which was originally designed to meet low volume vehicles. These heavy vehicles which now ply the road have further worsened the problem of road failure along Ilorin-Ajase Ipo road.

\section{Relationship Between Road Failure And Engineering Properties}

The result of the stepwise regression presented in table .2 showed that, geotechnical properties of the foundation of the road contribute to $99.7 \%$ to the variance in the explanation of road failure and a road failure model was generated thus.

$$
\begin{aligned}
& Y=1734.4+9.908 \mathrm{Cu}+14.814 \mathrm{Ccvr} \ldots \ldots \ldots . . . \mathrm{eqn}(1.1) \\
& \left(\mathrm{R}^{2}=99.7 \% ; \mathrm{SE}=3.40\right)
\end{aligned}
$$

Coefficient of curvature $(\mathrm{Cu})$ and Coefficient of Curvature (Ccvr) as explained by this model shows that, two variance contributed to $99.7 \%$ to the explanation to road failure. This result confirms the level of poor gradation of the foundation materials as indicated above in the table 1 Suggesting poor gradation of foundation of the road therefore, the foundation materials of the road is poorly graded meaning that the road is not stable in the study area.

\section{Conclusion And Implication Of Study}

Geotechnical properties of the foundation of the road have significantly affected the rate of road failure along Ilorin- Ajase-Ipo road. Results have indicated that geotechnical properties were not properly analyzed before construction started to identify areas with problem soils which are threatening the road today with various forms of failures. It is also evidently clear from the findings that, the presence of clayey soil and sandy soil which were poorly graded have caused cracks, bulges which result to series of potholes and depression on the road. However, poor engineering construction also contribute to the rate of failure, it has been observed that the bituminous pavement of the road falls between $45-50 \mathrm{~mm}$ which is far below engineering specification of $150-200 \mathrm{~mm}$ British standard for flexible pavement (cited in O'Flaherty 2001). Absence of drainage facility to discharge concentration of run-off especially during wet season and where drainage facilities is present it is completely covered with sediments, the concentration of run off on the road also affects compaction rate of the road foundation hence weaken the stability of the foundation of the road. Implication of this to road failure is that, poor engineering construction and problem-soils has caused the government millions of naira to maintain roads annually more so, maintenance carried out yielded no result because maintenance have been approached wrongly by relevant government agencies. In addition, heavy vehicles now ply the road with several tones of materials have further worsening the situation of road failure along Ilorin-Ajase Ipo road Kwara State, Nigeria.

\section{References}

[1] Adesunloye M.O (1987) Investigating the problem soils in Nigeria. $9^{\text {th }}$ Regional Conference on Soil Mechanics and foundation Engineering For Africa. Vol.1. Balkema/Roterdam/Boston103 -112.

[2] Bolarinwa A.(2010) Geotechnical properties of major problem Soils of Nigeria www.Google.com hub pages Technology.

[3] Chukweze H.O. (1991) Geotechnical and geological properties of tropical Soils. $9^{\text {th }}$ Regional Conference on Soil Mechanics and foundation engineering For Africa.Vol.2.Balkema/Rotterdam/Boston.731-735.

[4] Durotoye .B. (1983) Geomorphology and quaternary deposits of Nigeria.In: Ola.S.A (ed) Tropical Soils of Nigeria in Engineering Practice.1-15

[5] Federal Road Safety Corps( FRSC 2011) United Nation Dacade of Action on Road Safety.Benin City Nigeria

[6] O'Flaherty C.A (1979) Highway Engineering Edward Arnold - London

[7] O'flaherty C.A (2001) soils for Road work: In O'flaherty, C.A. (ed). Highways the location,Design, Construction and maintenance of pavements. 133.www.amazon.com.

[8] Ojo O. (1977) The climate of West Africa Heinethann Press.

[9] Olaniran O.J (2002) Rainfall Anomalies in Nigeria: The Contemporary understanding $55^{\text {th }}$ Inaugural lecture, University of Ilorin, Nigeria. Unilorin Press, University of Ilorin. 8-10.

[10] Ola .S.A.(1983) Geotechnical properties and behaviour of some Nigerian lateritic Soils.In:Ola.S.A (ed) Tropical Soils of Nigeria in Engineering practice.61-84.

[11] Omange .G.N, Nnama.S..K, and Aitsebaomo .F.O (1988).Engineering characteristics of sub Grade Soils of Nigeria and application to economic pavement design. Road Research.NBRRI.135-179

[12] Oyegun R. O. (1986) Water Resources in Kwara State. Matanmi and Sons printing and publishing Co.Ltd. Ilorin, Kwara State. 